\title{
Localization of Collagenase in the Growth Plate of Rachitic Rats
}

David D. Dean, Ofelia E. Muniz, Inwin Berman, Julio C. Pita, Manuel R. Carreno, J. Frederick Woessner, Jr., and David S. Howell

Departments of Biochemistry, Medicine, and Anatomy-Cell Biology, University. of Miami School of Medicine, P. O. Box 016960, Miami, Florida 33101

\begin{abstract}
In the transition from proliferating to hypertrophic cell zones in the growth plate, there is an increase in chondrocyte volume and a corresponding decrease in collagen content to accommodate the enlarging cells. It is postulated that collagenase accounts for this collagen loss. To test this hypothesis, tibial growth plates were obtained from normal rats, rachitic rats deficient in vitamin $D$ and phosphate, and rats after $\mathbf{4 8}$ and 72 $h$ of healing from rickets. Collagenase was quantitated by a pellet assay based on the release of solubilized collagen from the endogenous insoluble collagen in the tissue homogenates. A fourfold greater collagen release and a concomitant sixfold greater hypertrophic cell volume were measured in rachitic growth plates compared with normal age-matched controls. During healing of rickets, collagenase activity and hypertrophic cell volume returned almost to control levels. Rachitic growth plates were dissected into the juxtaepiphyseal $1 / 3$ and the juxtametaphyseal $2 / 3$. The latter portion contained $>95 \%$ of the hypertrophic cells and $86 \%$ of the collagenase. The collagendegrading activity was extracted from this region and was shown to be a true collagenase by its production of typical $A$ fragments of tropocollagen produced by collagenase action. The enzyme was activated by aminophenylmercuric acetate and trypsin and was inhibited by EDTA, 1,10-phenanthroline, and a tissue inhibitor of metalloproteinases from human articular cartilage. Inhibitors of aspartic, cysteine, and serine proteases had no effect. Micropuncture fluids aspirated from rachitic cartilage contained latent collagenase activity, indicating an extracellular localization. Negative tests for hemoglobin in the rachitic cartilage samples indicated that there was no contamination by capillaries and that this was not a source of collagenase. It is concluded that extracellular collagenase accounts for the loss of cartilage matrix in the hypertrophic zone, and that this process may be distinct from that of capillary invasion.
\end{abstract}

\section{Introduction}

Calcification of growth cartilage results from a complex sequence of events that are poorly understood. Mineral deposition occurs extracellularly in a transforming matrix comprising collagens (1, 2), glycoproteins (3), matrix vesicles (4), and proteoglycans $(5,6)$. Events that prepare the matrix for calci-

Address reprint requests to Dr. Howell, Department of Medicine D26, University of Miami School of Medicine, P.O. Box 016960, Miami, FL 33101.

Received for publication 2 November 1984.

J. Clin. Invest.

(c) The American Society for Clinical Investigation, Inc.

0021-9738/85/08/0716/07 \$1.00

Volume 76, August 1985, 716-722 fication are difficult to study in normal growth plates because of the very narrow zone in which mineralization occurs; this severely limits the size of samples for biochemical analysis. However, previous studies have shown that the sequence of mineralization events in healing rachitic rats closely duplicates the normal process, except that the hypertrophic zone is vastly expanded (7). This model facilitates biochemical analysis. It has been shown that a macromolecular proteoglycan inhibitor potently inhibits mineral growth in this system (8). An organic factor that rapidly generates mineral in the presence of metastable levels of mineral ions has also been detected in this system (9). The extracellular location of aspirated micropuncture fluid has been firmly documented (10). The current study is a continuation of this series of characterizations; it addresses the problem of hypertrophic cell enlargement adjacent to the site of fluid collection in the expanded rachitic growth plate. The hypothesis that collagen is removed by action of collagenase is tested by a direct tissue assay for collagenase activity. Evidence is presented that the enzyme is not produced by invading capillaries.

\section{Methods}

Animal and tissue preparation. Male Sprague-Dawley rats (35-45 g; Charles River Breeding Laboratories, Inc., Wilmington, MA) at age 21 d were randomly assigned to three different regimens. Group I, normal controls, were kept for 21-24 d on rat chow diet (Ralston Purina Co., St. Louis, MO) and water ad lib. Group II, animals rachitic due to low phosphate, vitamin D-deficient diet (-VDP)', were kept in the dark on U. S. Pharmacopeia Rachitogenic Diet No. 12 (calcium to phosphorus ratio, 5.85; Teklab Test Diets, Madison, WI) lacking vitamin D to induce -VDP rickets as described earlier $(8,11)$. Group III, healing rachitic animals, received a single oral dose of vitamin D (Eli Lilly Co., Indianapolis, IN; ergocalciferol, 2,000 IU) after $21 \mathrm{~d}$ on the rachitogenic regimen. During healing, the rats were fed normal rat chow (Ralston Purina Co.) and water ad lib. for 2-3 d. All animals were sacrificed with sodium pentobarbital (10\% in sterile water).

Histology and morphometry. The growth cartilage from the proximal tibias of both legs was excised from the surrounding tissues and trimmed under a dissecting microscope to exclude metaphyseal tissue and perichondrium. The tissue was then washed with sterile saline, blotted on tissue paper, and prepared for morphometry or enzyme assay. In some experiments the growth plates were also cut into two pieces: either the upper one-third (i.e., one-third of the distance from the resting cells to the mineralizing front) and lower two-thirds or the upper and lower one-half sections.

For histology, the tissues were fixed in $10 \%$ neutral formalin, decalcified in $0.5 \%$ formic acid for $1.5 \mathrm{~h}$, embedded in paraffin, cut

1. Abbreviations used in this paper: APMA, aminophenylmercuric acetate; Cfl, cartilage extracellular fluid sampled by micropuncture aspiration; Hyp, hydroxyproline; $\mathrm{TC}^{\wedge}$, the $\mathrm{A}$ fragment of tropocollagen produced by collagenase action; TIMP, tissue inhibitor of metalloproteinases; -VDP, animals rachitic due to low phosphate, vitamin D deficient diet. 
into 5- $\mu \mathrm{m}$ serial sections, stained with $0.2 \%$ Safranin O (Sigma Chemical Co., St. Louis, MO), and counterstained with $0.1 \%$ Light Green SF Yellow. Morphometric analysis of cells and matrix in the proliferative and hypertrophic zones was performed according to standard stereological methods (12) under phase contrast microscopy (magnification of 320) using an ocular (E. Leitz, Inc., Rockleigh, NJ) containing a coherent lattice grid with a total of 324 points. The volume density measurements obtained by this method provide quantitative estimates of the fraction of total tissue volume occupied by the cells. The average number of fields scored per slide was approximately 12 and the total number of points scored per slide was approximately 3,800 . Data were collected from six random sections from six animals in each experimental group. Statistical tests included analysis of variance and StudentNewman-Keuls multiple comparison test (13).

Collagenase assay in tissue pellets. The assay is based on the principle that collagenase will digest endogenous collagen when homogenates are incubated at $37^{\circ} \mathrm{C}$. Insoluble collagen is separated from solubilized digestion products by centrifugation and the two collagen fractions are quantitated by their content of hydroxyproline (Hyp). Homogenates were prepared by the method of Morales et al. (14) and modified as follows. Epiphyseal growth plate cartilage $(100 \mathrm{mg})$ was dissected, weighed, and placed in 25 vol ice-cold assay buffer $(0.05 \mathrm{M}$ Tris/ $\mathrm{HCl}, 0.01 \mathrm{M} \mathrm{CaCl}_{2}, 0.15 \mathrm{M} \mathrm{NaCl}$, pH 7.6, with $100 \mathrm{U}$ penicillin and $100 \mu \mathrm{g}$ streptomycin $/ \mathrm{ml}$ ). The tissue was homogenized at $4^{\circ} \mathrm{C}$ using a hand-driven glass homogenizer (Duall $\# 20$; Kontes Co., Vineland, NJ). Cartilage pellets were prepared by centrifuging at $10,000 \mathrm{~g}$ for $20 \mathrm{~min}$ at $4^{\circ} \mathrm{C}$ and resuspending in the original volume of assay buffer.

Collagenase was activated by adding $5 \mu \mathrm{l}$ of trypsin $(0.5 \mathrm{mg} / \mathrm{ml}$; Worthington Diagnostics Div., Millipore Corp., Freehold, NJ) to 250 $\mu l$ of resuspended pellet. Samples were then incubated at $37^{\circ} \mathrm{C}$ for 3 min, cooled in an ice bath, and treated with $5 \mu l$ soybean trypsin inhibitor $(2.5 \mathrm{mg} / \mathrm{ml}$; Worthington Type Is) to block the trypsin. Alternatively, collagenase was activated with $1 \mathrm{mM}$ aminophenylmercuric acetate (APMA). To determine optimal levels of activators and cofactors, various tests were performed. Trypsin activation was examined by adding trypsin to hypertrophic cell pellets, incubating for $3 \mathrm{~min}$ at $37^{\circ} \mathrm{C}$, and stopping the reaction with a fivefold weight excess of soybean trypsin inhibitor. APMA activation was tested by adding it at various levels to the incubation mixture. The calcium requirement was studied by varying the level of this ion with enzyme activated by APMA. To determine whether a second divalent cation was required, the enzyme was preincubated with $1 \mathrm{mM}$ EDTA for $1 \mathrm{~h}$ at $37^{\circ} \mathrm{C}$ in calcium-free assay buffer and then assayed in the presence of $1 \mathrm{mM}$ APMA and $10 \mathrm{mM} \mathrm{CaCl}_{2}$. Alternatively, the enzyme was inhibited with $1 \mathrm{mM} \mathrm{1,10-phenanthroline} \mathrm{in} \mathrm{the} \mathrm{presence} \mathrm{of} \mathrm{excess} \mathrm{calcium.}$

Incubations were performed in 1-ml Microflex tubes (Kontes Co.) with $250-\mu \mathrm{l}$ aliquots of the pellet homogenates prepared as above. The samples were paired and treated in four different ways. Group I contained the suspension alone, to test for enzyme already in an active form. Group II had added $1 \mathrm{mM} \mathrm{1,10-phenanthroline} \mathrm{to} \mathrm{block}$ collagenase (= blank). Group III was treated with 1 mM APMA to activate latent collagenase. Group IV contained APMA and either 20 mM EDTA or $1 \mathrm{mM}$ phenanthroline to serve as a blank for III. After incubation for $18 \mathrm{~h}$ at $37^{\circ} \mathrm{C}$, the samples were centrifuged at $3,000 \mathrm{~g}$ for $20 \mathrm{~min}$ at $4^{\circ} \mathrm{C}$. The supernatant was transferred to a Microflex tube and an equal volume of $12 \mathrm{~N} \mathrm{HCl}$ was added. The pellets were resuspended to their original volume with $6 \mathrm{~N} \mathrm{HCl}$. The tubes were sealed with Teflon-lined caps and incubated at $110^{\circ} \mathrm{C}$ overnight.

After hydrolysis, the hydroxyproline assay of Morales et al. (14) was used. The samples were dried on a steam bath in a gentle stream of air. The dried samples were resuspended in $200 \mu \mathrm{l}$ of a 1:4 dilution of the original citric acid buffer, and $5 \mu \mathrm{l}$ of $0.02 \%$ methyl red was added. The pH was adjusted to 6.0 and the volume to $250 \mu$ l. The colorimetric assay of Woessner (15) was then performed, reducing the volume of each reagent to give a final volume of $1.25 \mathrm{ml}$. After color development, the samples were extracted twice with $900 \mu l$ of toluene to remove interfering substances, and absorbance was measured at 557 nm. The collagenase activity was expressed as percent collagen digested: (micrograms Hyp solubilized/micrograms total Hyp in pellet and supernatant) $\times 100$. Correction was made for the blank obtained in the presence of chelator.

Micropuncture fluid collagenase. To determine the enzyme activity present in cartilage micropuncture fluid, a microscale assay was employed, using soluble type I collagen purified from rat skin (see below). On three occasions, a 100-nl sample of cartilage fluid (Cfl) was obtained by aspiration from six rachitic rats as previously described (11). Collagenolytic activity was measured by incubating the Cil sample with $20 \mu \mathrm{g}$ unlabeled acid-soluble collagen for $48 \mathrm{~h}$ at $37^{\circ} \mathrm{C}$ in $50 \mathrm{mM}$ Tris/ $\mathrm{HCl}, 0.2 \mathrm{M} \mathrm{NaCl}, 10 \mathrm{mM} \mathrm{CaCl}, 0.02 \%$ sodium azide, $\mathrm{pH}$ 7.5. Blanks contained 1,10-phenanthroline. After centrifugation at 10,000 $g$ for $20 \mathrm{~min}$ to remove undigested fibrils, the dried, hydrolyzed supernatants were suspended in $15 \mu \mathrm{l}$ citric acid buffer, while the dried pellet was suspended in $50 \mu$ l. Reagent volumes were adjusted to give a final volume, after color development, of $75 \mu \mathrm{l}$ for the supernatant and $250 \mu \mathrm{l}$ for the pellet. The absorbancy was read in a previouslydescribed microcuvette (16). The activity was calculated as above for the pellet assay.

Extraction of collagenase. The extraction of enzyme followed the method of Sellers and Woessner (17) with slight modification. The lower two-thirds of the rachitic rat growth plate, containing the hypertrophic zone (100-120 mg from six rats), was homogenized with a hand-driven glass homogenizer (Duall \#20; Kontes Co.) in $10 \mathrm{vol}$ ice-cold $0.01 \mathrm{M} \mathrm{CaCl}_{2}$ containing $0.25 \%$ Triton X-100. The homogenates were centrifuged at $4^{\circ} \mathrm{C}$ for $20 \mathrm{~min}$ at $10,000 \mathrm{~g}$. The pellet was resuspended in one-half the original volume of $0.05 \mathrm{M}$ Tris/ $\mathrm{HCl}, 0.1$ $\mathrm{M} \mathrm{CaCl}_{2}, \mathrm{pH} 7.5$, and heated for $4 \mathrm{~min}$ at $60^{\circ} \mathrm{C}$. Additional collagenase was extracted by repeating this heat step. The enzyme was activated by incubating with $0.5 \mathrm{mM}$ APMA for $1 \mathrm{~h}$ at $37^{\circ} \mathrm{C}$, followed by dialysis against assay buffer.

Assay of extracted collagenase on telopeptide-free collagen. Acid soluble type I collagen was obtained from rat skins by extraction in $0.5 \mathrm{M}$ acetic acid. The solubilized collagen was precipitated with 1.7 $M \mathrm{NaCl}$, dissolved in $50 \mathrm{mM}$ Tris/HCl, $2 \mathrm{M}$ urea, $0.3 \mathrm{M} \mathrm{NaCl}, \mathrm{pH}$ 7.5 , and then dialyzed against the same buffer without urea. The product was precipitated with ammonium sulfate $(176 \mathrm{mg} / \mathrm{ml})$ and then dissolved in $0.5 \mathrm{M}$ acetic acid. Pepsinization and subsequent purification were carried out as described by Ryhanen et al. (18). The purified collagen was then acetylated with $\left[{ }^{3} \mathrm{H}\right]$ acetic anhydride $(50$ $\mathrm{mCi} / \mathrm{mmol}$; New England Nuclear, Boston, MA) at a ratio of $1 \mathrm{mCi} / 20$ $\mathrm{mg}$ collagen as previously described $(19,20)$. The specific activity of the final product was $6.5 \times 10^{3} \mathrm{cpm} / \mu \mathrm{g}$ and the collagen was homogenous on sodium dodecyl sulfate (SDS) polyacrylamide gel electrophoresis.

The method for measuring extracted collagenase activity was modified from that of Ryhanen et al. (18). Telopeptide-free rat skin collagen $\left(9 \mu \mathrm{g}, 6 \times 10^{4} \mathrm{cpm}\right)$ was incubated with enzyme for $18 \mathrm{~h}$ at $30^{\circ} \mathrm{C}$ in a total volume of $110 \mu$. The reaction was stopped with EDTA, carrier type I collagen without label was added, followed by trypsin and chymotrypsin to digest the products of collagenase action. Trichloroacetic acid was used to precipitate undigested collagen, which was then recovered on glass fiber filters. The filters were placed in 10 $\mathrm{ml}$ of scintillation fluid (Aquasol; New England Nuclear) and counted in a scintillation counter (Tri-Carb; Packard Instrument Co., Downers Grove, IL). Results were calculated as percent digestion after correction for buffer blanks. The assay was found to be linear with time over 24 $\mathrm{h}$ and up to $50 \%$ digestion of the collagen (not shown).

SDS-gel electrophoresis of collagenase-digested collagen. Enzyme extracts were incubated with $9 \mu \mathrm{g}$ tritiated, acid-soluble, telopeptidefree, type I collagen for $18-72 \mathrm{~h}$ at $30^{\circ} \mathrm{C}$. The reaction was stopped by making the sample $40 \mathrm{mM}$ in EDTA and then denaturing for 5 min at $100^{\circ} \mathrm{C}$ in $0.06 \mathrm{M}$ Tris/ $\mathrm{HCl}, 2 \% \mathrm{SDS}, 10 \%$ glycerol, $0.01 \%$ bromphenol blue, $2.5 \% \beta$-mercaptoethanol, $\mathrm{pH}$ 7.5. The sample was then electrophoresed in a $7.5 \%$ SDS-polyacrylamide slab gel $(0.75 \mathrm{~mm}$ thick) using the Laemmli procedure (21). The gel was stained with silver according to Morrissey (22). 


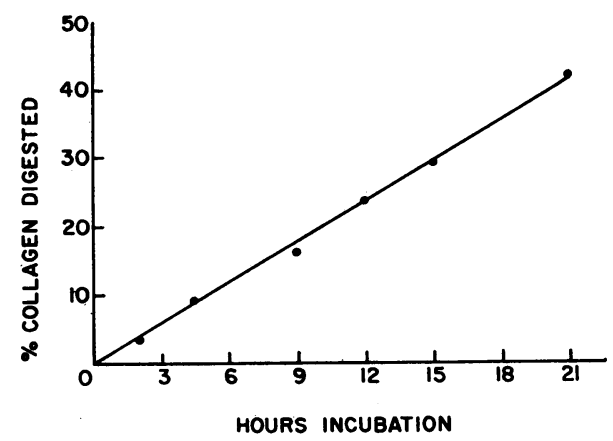

Figure 1. Digestion of endogenous collagen in the pellet assay as a function of time. Growth plates from rachitic rats were homogenized and prepared for assay as described in Methods. Resuspended pellets were activated with $1 \mathrm{mM}$ APMA and incubated for the various times shown in the figure. The extent of digestion was then determined by Hyp assay.

\section{Results}

A pellet assay was used to quantitate collagenolytic activity in the rat growth plate. This assay involves measuring the release of Hyp-containing peptides from the endogenous collagen in the tissue samples. This method was chosen in preference to culture methods because it shows the activity present directly in the tissue at the time of excision. While it is possible to extract collagenase from the growth plate and assay it directly (see below), this approach is not suitable for routine assay because it requires too much tissue and the extraction is not quantitative. Labeled collagen could be added to the pellet assay, but this would require demonstration that the digestion of the added collagen was proportional to the digestion of endogenous collagen, i.e., that collagenase bound to endogenous collagen could move freely to the added substrate. For these reasons the pellet assay was adopted for routine use.

The pellet assay was shown to be linear over a 21-h incubation period and up to $42 \%$ digestion (Fig. 1). In addition, since this method was originally developed for another tissue in which type I collagen was present (14), the duration of centrifugation and the $g$-force were varied to determine the conditions necessary for pelleting the thinner type II collagen fibrils after the overnight incubation. It was found that the same amount of peptide-bound Hyp was present in the supernatant after centrifuging for either $30 \mathrm{~min}$ at $100,000 \mathrm{~g}$ or 20 min at $3,000 \mathrm{~g}$; thus, the lower speed is adequate. Although these results establish the validity of this method for studying collagenolysis, the action of nonspecific metalloproteases cannot be completely excluded. Thus, we can't be certain that part of the collagen did not become denatured during the assay, or that we measured only type II collagen digestion and not that of type I or other minor collagens.

Using the pellet assay, whole growth plates from the four groups of animals were processed for collagenolytic activity (Table I). As can be seen, the Hyp content and tissue weight for the first three groups showed little change, but there was some decline in the last group. Collagenase activity, both total and active, increased almost fourfold in rickets, then returned to normal during healing. The cell volume showed only a twofold increase in rickets; however, this increase was due largely to an increase in the volume of hypertrophic cells (5.8fold), whereas proliferative cell volume increased only slightly (1.5-fold). Thus, the change in collagenase level appears to correlate most closely with the change in hypertrophic cell volume. Statistical comparisons of the means of the various groups are summarized in Table II. We also examined 100-nl samples of micropuncture fluid. Three samples of rachitic fluid contained collagenase that, when activated by APMA, digested $1.71 \pm 0.27 \mu \mathrm{g}$ collagen in $48 \mathrm{~h}$ at $37^{\circ} \mathrm{C}$ using intact type I collagen as substrate. This constitutes further proof of the existence of a true collagenase in the cartilage.

The growth plates were sectioned into regions to determine if the enzyme activity would segregate with the hypertrophic cells as the above observations suggested. When the growth plates were cut in half, $62 \%$ of the total hypertrophic cell volume and only $8 \%$ of the proliferative cell volume was found in the lower half along with $58 \%$ of the collagenase (Table III). Other growth plates were sectioned into upper one-third $(63 \%$

Table I. Comparison of Hypertrophic Cell Volume with Collagenase Activity for Whole Growth Plate Cartilage*

\begin{tabular}{|c|c|c|c|c|}
\hline & Normal & Rachitic & 48-h healing & 72-h healing \\
\hline No.ł & 6 & 6 & 8 & 8 \\
\hline Tissue weight $(m g)$ & $160 \pm 8.9$ & $175 \pm 12$ & $150 \pm 6.7$ & $109 \pm 8.1$ \\
\hline$\mu \mathrm{g} \mathrm{Hyp/mg} \mathrm{wet} \mathrm{tissue}$ & $2.3 \pm 0.09$ & $2.4 \pm 0.06$ & $2.4 \pm 0.14$ & $2.0 \pm 0.04$ \\
\hline Active collagenase $\$$ & $2.5 \pm 0.33$ & $8.9 \pm 1.8$ & $3.5 \pm 0.4$ & $2.4 \pm 0.3$ \\
\hline Total collagenase & $10.2 \pm 1.3$ & $39.0 \pm 3.5$ & $10.3 \pm 0.8$ & $4.6 \pm 0.4$ \\
\hline No.I & 6 & 6 & 6 & 6 \\
\hline Total cell volume density $\times 10^{-3}$ & $65.4 \pm 4.2$ & $144.9 \pm 2.6$ & $53.9 \pm 3.2$ & $47.8 \pm 3.1$ \\
\hline Hypertrophic cell volume density $\times 10^{-3}$ & $10.8 \pm 0.5$ & $62.6 \pm 8.3$ & $14.5 \pm 1.1$ & $13.5 \pm 1.5$ \\
\hline Hypertrophic cell volume as percent total cell volume & 16.5 & 43.2 & 26.9 & 28.2 \\
\hline Proliferative cell volume density $\times 10^{-3}$ & $54.6 \pm 4.5$ & $82.3 \pm 9.8$ & $39.4 \pm 3.6$ & $34.4 \pm 3.6$ \\
\hline Proliferative cell volume as percent total cell volume & 85.5 & 56.8 & 73.1 & 71.2 \\
\hline Fold HCV/fold PCV** & 1.0 & 3.86 & 1.86 & 1.76 \\
\hline
\end{tabular}

* All values are given as mean \pm SEM. $¥$ Number of groups of animals tested, six animals per group. $\S$ Percent of Hyp solubilized in the pellet assay, corrected for EDTA blank. "As in footnote $\S$, except $1 \mathrm{mM}$ APMA was added to activate latent enzyme. I Numbers of animals analyzed by point stereology. ** Fold change in hypertrophic cell volume compared with normal/fold change in proliferative cell volume compared with normal. 
Table II. Statistical Analyses for Collagenase Activity and Cell Volume Density in Whole Growth Plate Cartilage

\begin{tabular}{|c|c|c|c|}
\hline & Rachitic & 48-h healing & 72-h healing \\
\hline \multicolumn{4}{|c|}{ Active collagenase } \\
\hline Normal & 0.001 & NS & NS \\
\hline Rachitic & & 0.01 & 0.001 \\
\hline 48-h healing & & & NS \\
\hline \multicolumn{4}{|l|}{ Total collagenase } \\
\hline Normal & 0.001 & NS & NS \\
\hline Rachitic & & 0.001 & 0.001 \\
\hline 48-h healing & & & 0.05 \\
\hline \multicolumn{4}{|c|}{$\begin{array}{l}\text { Proliferative cell volume } \\
\text { density }\end{array}$} \\
\hline Normal & 0.01 & NS & 0.05 \\
\hline Rachitic & & 0.001 & 0.001 \\
\hline 48-h healing & & & NS \\
\hline \multicolumn{4}{|c|}{$\begin{array}{l}\text { Hypertrophic cell } \\
\text { volume density }\end{array}$} \\
\hline Normal & 0.01 & NS & NS \\
\hline Rachitic & & 0.001 & 0.001 \\
\hline 48-h healing & & & NS \\
\hline
\end{tabular}

Analysis of variance was performed for the four groups of animals for each of the four parameters listed. In each case significance was found. The individual groups were then tested by the StudentNewman-Keuls test (13). NS = not significantly different.

proliferative cells) and lower two-thirds (95\% hypertrophic cells). In this case, $86 \%$ of the collagenase activity was in the lower two-thirds; this corroborates the conclusion reached above that the enzyme is predominantly in the same region as the hypertrophic cells.

Some of the properties of the enzyme in the pellet assay are indicated in Table IV. The enzyme was activated with either $0.5 \mathrm{mM}$ APMA or $10 \mu \mathrm{g} / \mathrm{ml}$ of trypsin and it required $10 \mathrm{mM} \mathrm{CaCl} 2$ for optimal activity. When the pellets were treated with low levels of EDTA after homogenization in calcium-free buffer, metalloprotease activity was blocked and the residual activity $(4.5 \%)$ is attributed to action of nonspecific proteases or simple solubilization. If excess calcium $(10 \mathrm{mM})$ is added, activity rises to $19 \%$ digestion, but not to the full value of 55\%. This indicates that a second divalent cation such as zinc is probably required for full activity.

The collagenase activity in the lower two-thirds of rachitic growth plates was extracted by heating to $60^{\circ} \mathrm{C}$ for $4 \mathrm{~min}$ in $0.1 \mathrm{M} \mathrm{CaCl}_{2}$ after an initial homogenization in Triton X-100. This method has been used in our laboratories for extracting collagenase and neutral metalloproteases from the rat uterus (17) and proved effective with the growth plate as well. No further attempts were made to optimize the extraction since six animals were required for each new protocol. We plan to explore this point further in future work.

The properties of the extracted enzyme were investigated by use of the soluble collagen assay. It was found that the enzyme could be activated with APMA and trypsin and required calcium for activity, as in the pellet assay. These measurements avoided the $4.5 \%$ background seen with the pellet assay in the presence of chelators; inhibition by EDTA or phenanthroline was virtually complete. In addition, the enzyme digested soluble collagen in linear fashion up to $72 \mathrm{~h}$ incubation and up to $50 \%$ digestion of the substrate (data not shown). Growth plate collagenase produced the classic A fragment of tropocollagen ( $\mathrm{TC}^{\mathrm{A}}$ ) (Fig 2); the B fragments of tropocollagen produced by collagenase action were not readily visible and have probably been degraded by other proteases in the extract. The enzyme was also inhibited by tissue inhibitor of metalloproteinases (TIMP) (see ref. 23) isolated from human articular cartilage. Based on these observations, the enzyme activity associated with the release of Hyp from growth plate is a true collagenase.

\section{Discussion}

Our studies have shown for the first time that the hypertrophic region of rachitic growth cartilage produces a true collagenase. This activity has been studied using three different assay methods. The pellet assay is quantitative, but not completely specific; it measures only metal-dependent proteolysis, but this could include gelatinase as well as collagenase. If one accepts

Table III. Distribution of Hypertrophic Cell Volume and Collagenase Activity in -VDP Growth Plate

\begin{tabular}{|c|c|c|c|c|}
\hline & \multicolumn{4}{|c|}{ Relative division of the growth plate } \\
\hline & Upper one-half & Lower one-half & Upper one-third & Lower two-thirds \\
\hline No. for collagenase* & 4 & 4 & 6 & 6 \\
\hline Tissue wet weight $(\mathrm{mg})$ & $104 \pm 7.0$ & $102 \pm 6.0$ & $64.3 \pm 6.0$ & $117 \pm 6.1$ \\
\hline$\mu \mathrm{g}$ Hyp/mg tissue & $2.6 \pm 0.2$ & $2.0 \pm 0.18$ & $3.06 \pm 0.18$ & $2.13 \pm 0.22$ \\
\hline Active collagenase $\ddagger$ & $3.2 \pm 0.2$ & $19.4 \pm 0.88$ & $2.7 \pm 0.5$ & $17.1 \pm 0.7$ \\
\hline Total collagenase & $34 \pm 3.5$ & $47.4 \pm 5.8$ & $7.0 \pm 1.7$ & $43 \pm 5.2$ \\
\hline Percent total collagenase in each region & 42 & 58 & 14 & 86 \\
\hline No. for sterology§ & 6 & 6 & 6 & 6 \\
\hline Total hypertrophic cell vol. density $\times 10^{-3 \|}$ & 61.9 & 61.9 & 61.9 & 61.9 \\
\hline Hypertrophic cell vol. density $\times 10^{-3}$ & $23.2 \pm 5.9$ & $38.6 \pm 2.2$ & $3.4 \pm 1.8$ & $58.5 \pm 5.8$ \\
\hline \% Hypertrophic cell vol. in each region & 38 & 62 & 5.5 & 94.5 \\
\hline
\end{tabular}

* Number of groups, six animals per group. ¥ Expressed as percent of total Hyp released to the supernatant, corrected for EDTA blank. $\S$ Number of samples analyzed by point stereology. "Calculated by adding the values from the two regions. 
Table IV. Activation and Inhibition of Hypertrophic Cell Collagenase*

\begin{tabular}{lc}
\hline Treatment & Percent Hyp released \\
\hline Aminophenylmecuric acetate & \\
None & $23 \pm 5.5$ \\
$0.5 \mathrm{mM}$ & $55 \pm 7.5$ \\
$1.0 \mathrm{mM}$ & $55 \pm 5.1$ \\
Trypsin & \\
None & $24 \pm 5.0$ \\
$10 \mu \mathrm{g} / \mathrm{ml}$ & $50 \pm 6.8$ \\
$30 \mu \mathrm{g} / \mathrm{ml}$ & $50 \pm 6.8$ \\
Calcium & \\
None & $15 \pm 6.0$ \\
$5 \mathrm{mM}$ & $42 \pm 3.9$ \\
$10 \mathrm{mM}$ & $50 \pm 8.2$ \\
$1 \mathrm{mM}$ EDTA, no calcium & $4.5 \pm 0.56$ \\
$1 \mathrm{mM}$ EDTA, then $10 \mathrm{mM} \mathrm{CaCl}$ & $19.3 \pm 0.7$ \\
Protease inhibitors & \\
Pepstatin (10 $\mu \mathrm{g} / \mathrm{ml})$ & $48 \pm 4.7$ \\
N-ethylmaleimide $(1 \mathrm{mM})$ & $50 \pm 6.7$ \\
Phenylmethylsulfonyl fluoride $(1 \mathrm{mM})$ & $48 \pm 7.5$
\end{tabular}

* Collagenase was measured by the pellet assay using tissue from the lower two-thirds of rachitic rat growth plate.

$¥$ Treatments are described in Methods. The experiments in the calcium group and the protease inhibitor group had $1 \mathrm{mM}$ APMA to activate the enzyme. In the calcium group, the EDTA was added to calcium-free pellets for $1 \mathrm{~h}$ at $37^{\circ} \mathrm{C}$ and then incubated with $\mathrm{AMPA} \pm \mathrm{CaCl}_{2}$.

that gelatin is susceptible to nonspecific protease action, then the contribution from gelatin would probably be $<5 \%$ digestion (Table IV, EDTA). If the concentration of substrate were to vary widely from sample to sample (see Table I), this might affect the enzyme kinetics. In our studies, the 72-h healing samples were the only ones to contain significantly lower amounts of collagen per milligram wet tissue; therefore, substrate concentration was not a critical factor, with the possible exception of this group. We assume that the enzyme was saturated during these assays since the reaction rate was linear from 0-21 h (Fig. 1); and Welgus et al. (24) have shown that only $10 \%$ of fibrillar collagen is available for binding to the enzyme, the deeper molecules become exposed only after digestion of the outer layer.

The pellet assay includes minor collagens $(1 \alpha, 2 \alpha, 3 \alpha, \mathrm{M}$, $\mathrm{CF} 1$; cf. ref. 25), which might contribute to the release of Hyp; also, it will not differentiate between type I and type II collagen. For these reasons, we used a second, more specific assay, and showed that extracts of rachitic growth plate contain a true collagenase based on the cleavage of collagen to typical $\mathrm{TC}^{\mathrm{A}}$ fragments of collagen at $30^{\circ} \mathrm{C}$. Therefore, in the rachitic growth plate when $39 \%$ of the endogenous collagen is digested, there is no question that the bulk of this activity is due to the action of collagenase on type II collagen and not to gelatinase action or to digestion of minor collagens.

Of particular interest is the fact that the growth plate of the rachitic rats contains a large quantity of collagenase when compared with levels found in other tissues. A digestion of $39 \%$ (Table I) corresponds to $6.48 \mathrm{U} / \mathrm{g}$ wet tissue (1 unit = 1 $\mu \mathrm{g}$ collagen digested $/ \mathrm{min}$ at $37^{\circ} \mathrm{C}$ ). Human osteoarthritic car-

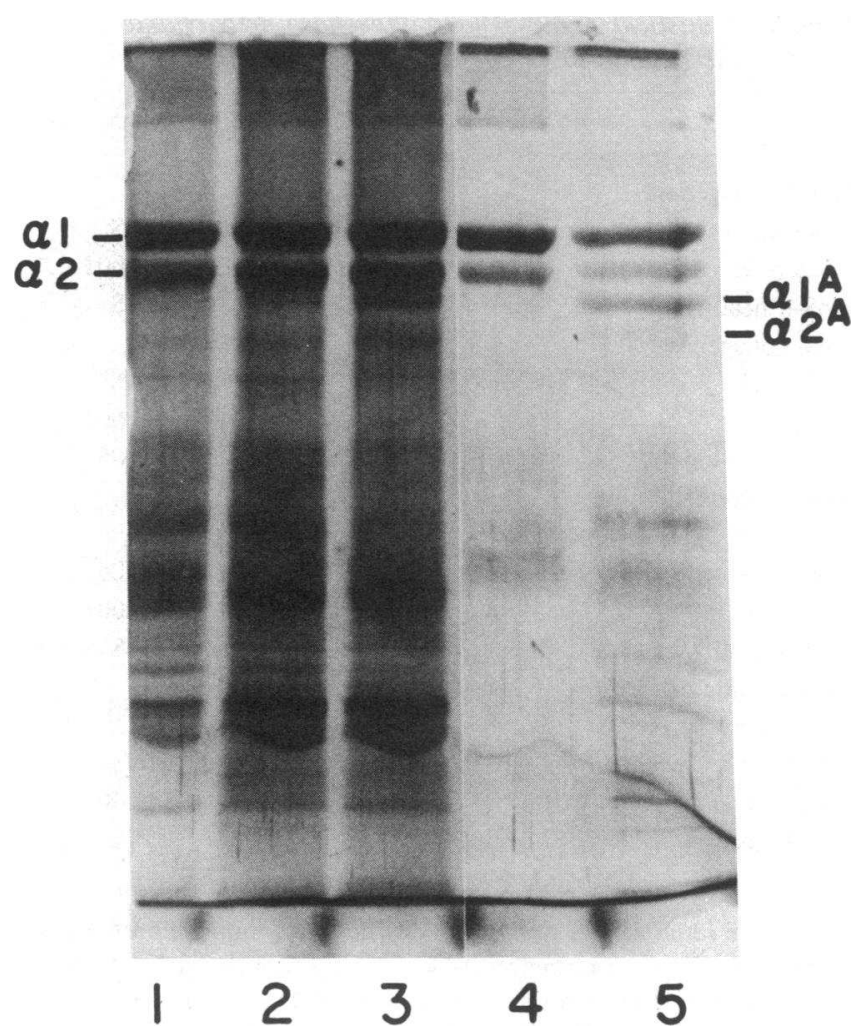

Figure 2. SDS-polyacrylamide gel electrophoresis of collagenase-digested collagen. Collagenase $(20 \mu \mathrm{l})$ extracted from the hypertrophic zone of rachitic rat growth plate was incubated with $9.2 \mu \mathrm{g}$ $\left[{ }^{3} \mathrm{H}\right]$ telopeptide-free collagen for 0 to $72 \mathrm{~h}$ at $30^{\circ} \mathrm{C}$. Digests were electrophoresed as described in Methods. A partially-purified collagenase from the rat uterus was used as a control. Lane 1, enzyme + collagen, not incubated. Lane 2, 18-h incubation. Lane 3, 72-h incubation. Lane 4, collagen incubated $72 \mathrm{~h}$ without added enzyme. Lane 5, rat uterus collagenase incubated $18 \mathrm{~h}$.

tilage (26) had an activity of $0.68 \mathrm{U} / \mathrm{g}$, only $1 / 10$ the level in growth plate. The involuting rat uterus, which has one of the fastest known rates of collagen breakdown (27), contained 6.2 $\mathrm{U} / \mathrm{g}$ tissue. In this latter case the substrate is type I collagen, which is generally found to be digested many times faster than type II (28). To extend the comparison, we used the assay based on type $\mathrm{I}^{3} \mathrm{H}$-labeled telopeptide-free collagen to measure the enzyme activity extracted from growth plate and from involuting uterus. In this assay, the units are measured at $30^{\circ} \mathrm{C}$, and cannot be directly compared with the units measured in the pellet assay at $37^{\circ} \mathrm{C}$. The growth plate had $7.7 \mathrm{U} / \mathrm{g}$ tissue and the uterus had $1.7 \mathrm{U} / \mathrm{g}$. This fourfold difference is consistent with results of the pellet assay in which the growth plate contained type II collagen and the uterus, type I; i.e., the growth plate collagenase digests type II collagen at about onefourth the rate for type I. This ratio is only an approximation, since we do not know the extent of extraction of collagenase from the growth plate.

Whereas cells in culture release collagenase almost totally in a latent form, we observed a considerable amount of enzyme in the growth plate that is active without treatment by APMA or trypsin. A recent publication by Robinson et al. (29) on a plasmin-dependent proteolytic system in mineralizing matrices might explain this finding, since plasmin can activate latent 
collagenase. In addition, it is possible that reduced levels of inhibitors like TIMP allow more active enzyme to be measured, while total enzyme would be accurately determined regardless of TIMP levels, since APMA destroys this inhibitor (23). Other neutral metalloproteinase activity, as described in articular cartilage by Woessner and Selzer (30), which degrades proteoglycan, was not detected in the heat extracts from the growth plate. The reason for this is not clear, but differences in rat and human tissue and the maturity of the cartilage may be factors.

The origin of growth plate collagenase is not yet established, but we believe that the hypertrophic cell is the most likely source. The collagenase activity increased fourfold when the hypertrophic cell volume increased sixfold. Division of growth plates into upper and lower regions further supports this hypothesis since most of the enzyme is found in the zone with the hypertrophic cells. The two zones of the growth plates could only be compared with each other in rickets; it was impossible to make such comparisons in normal specimens because of the narrow width of the cartilage. The accuracy of our dissecting technique was confirmed by histology (percent hypertrophic cell volume in each region, Table III). The Hyp/ milligram wet tissue levels were decreased in the lower region compared with the upper region, providing additional evidence for collagenolysis in vivo. It is doubtful that collagenase arises from the invading vessels, since activity is reduced when vascular invasion is maximal.

That the enzyme is extracellular is indicated by the fact that it could be measured in the micropuncture fluids. The fluid contained only latent enzyme, indicating that the active form is probably bound to collagen fibers (31).

In rickets, the increase in hypertrophic cell volume density is accompanied by an increase in collagenase. Collagenase is considered to be an extracellular enzyme, not stored in the cell (32). A given volume of rachitic growth plate will then contain six times more cells and four times more collagenase than normal. The simplest explanation for this is that the cells continue to produce collagenase in rickets at levels just slightly lower than normal. As the cell population increases, collagenase increases almost in parallel. As rickets heal, the collagenase level drops below the normal level by $72 \mathrm{~h}$, whereas the hypertrophic cell volume declines to a value still slightly above normal. This suggests that the hypertrophic cells during healing may diminish their production of collagenase. This is not unreasonable, if one considers that the space occupied by these cells has already been prepared and is now being consolidated by mineralization. These results on healing are surprising in light of the report by Amento et al. (33) that vitamin D stimulates monocytes to produce interleukin 1. Interleukin 1 should stimulate chondrocytes to produce increased amounts of collagenase. However, it is possible that there is no cellular source of interleukin 1 in the healing rachitic growth plate or that the recovering chondrocytes are insensitive to this factor.

Recently, Cheung et al. (34) have described the effects of hydroxyapatite and calcium pyrophosphate dihydrate crystals on chondrocytes in culture. They found elevated levels of collagenase, neutral protease, and prostaglandins when the cells were grown with these various types of crystals. It is not known how these precursors to mature forms of mineral could affect the cells in producing these enzymes, but the rachitic rat model may have some of the same precursors in vivo and this may result in elevated collagenase levels. Collagenase may not only be important in allowing for cell expansion during hypertrophy, but it may also be a critical link in the sequence of important and tightly regulated events that lead to endochondral calcification.

\section{Acknowledgments}

The authors would like to express their appreciation for the expert technical assistance provided by Ms. Agueda Agundez, Ms. Sara Morales, and Ms. Grace Tornero.

This project has been supported by National Institutes of Health grants HD-06773, AM-16940, and AM-08662; Research Service of the Veterans Administration; and the W. L. McKnight Arthritis Research Fund. Dr. Dean is a Fellow of the Arthritis Foundation.

\section{References}

1. von der Mark, K., and $H$. von der Mark. 1977. The role of three genetically distinct types of collagen in endochondral calcification of cartilage. J. Bone Jt. Surg. Br. Vol. 59B:458-464.

2. Yasui, N., K. Ono, H. Konomi, and Y. Nagai. 1984. Transitions in collagen types during endochondral ossification in human growth cartilage. Clin. Orthop. Relat. Res. 183:215-218.

3. Weiss, R. E., and A. H. Reddi. 1980. Synthesis and localization of fibronectin during collagenous matrix-mesenchymal cell interaction and differentiation of cartilage and bone in vivo. Proc. Natl. Acad. Sci. USA. 77:2074-2078.

4. Reinhold, F. P., A. Hjerpe, K. Jansson, and B. Engfeldt. 1984. Stereological studies on the epiphyseal growth plate in low phosphate, vitamin D-deficiency rickets with special reference to the distribution of matrix vesicles. Calcif. Tissue Int. 36:95-101.

5. Poole, A. R., I. Pidoux, and L. Rosenberg. 1982. Role of proteoglycans in endochondral ossification: immunofluorescent localization of link protein and proteoglycan monomer in bovine epiphyseal growth plate. J. Cell. Biol. 92:249-260.

6. Poole, A. R., A. H. Reddi, and L. Rosenberg. 1982. Persistence of cartilage proteoglycans and link protein during matrix induced endochondral bone development: an immunofluorescent study. Dev. Biol. 89:532-539.

7. McCollum, E. B., N. Simmonds, P. G. Shipley, and E. A. Park. 1922. Studies on experimental rickets: a delicate biological test for calcium depositing substances. J. Biol. Chem. 51:41-49.

8. Howell, D. S., J. C. Pita, J. F. Marquez, and R. A. Gatter. 1969. Demonstration of macromolecular inhibitor(s) of calcification and nucleation factors in fluid from calcifying sites in cartilage. J. Clin. Invest. 48:630-641.

9. Howell, D. S., J. C. Pita, and J. Alvarez. 1976. Possible role of extracellular matrix vesicles in initial calcification of healing rachitic cartilage. Fed. Proc. 35:122-126.

10. Howell, D. S., and J. C. Pita. 1976. Calcification of growth plate cartilage with special reference to studies on micropuncture fluid. Clin. Orthop. Relat. Res. 118:208-229.

11. Howell, D. S., J. C. Pita, J. F. Marquez, and J. E. Madruga. 1968. Partition of calcium, phosphate, and protein in the fluid phase aspirated at calcifying sites in epiphyseal cartilage. J. Clin. Invest. 47: 1121-1132.

12. Weibel, E. R., G. S. Kistler, and W. R. Scherely. 1966. Practical stereological methods for morphometric cytology. J. Cell Biol. 30:2338.

13. Zar, J. H. 1984. Biostatistical Analysis. Prentice Hall, Inc. Englewood Cliffs, NJ. 185-191.

14. Morales, T. I., J. F. Woessner, D. S. Howell, J. M. Marsh, and W. J. LeMaire. 1978. A microassay for the direct demonstration of collagenolytic activity in Graafian follicles of the rat. Biochim. Biophys. Acta. 524:428-434.

15. Woessner, J. F., Jr. 1961. The determination of hydroxyproline in tissue and protein samples containing small proportions of this imino acid. Arch. Biochem. Biophys. 93:440-447. 
16. Howell, D. S., J. C. Pita, and J. F. Marquez. 1966. Ultramicrospectrophotometric determination of calcium in biological fluids. Anal. Chem. 38:434-441.

17. Sellers, A., and J. F. Woessner, Jr. 1980. The extraction of a neutral metalloproteinase from the involuting rat uterus and its action on cartilage proteoglycan. Biochem. J. 189:521-531.

18. Ryhänen, L., S. Rantala-Ryhänen, E. M. L. Tan, and J. Uitto. 1982. Assay of collagenase activity by a rapid, sensitive and specific method. Collagen Rel. Res. 2:117-130.

19. Montelaro, R. C., and R. R. Rueckert. 1975. Radiolabelling of proteins and viruses in vitro by acetylation with radioactive acetic anhydride. J. Biol. Chem. 250:1413-1421.

20. Cawston, T. E., and A. J. Barrett. 1979. A rapid and reproducible assay for collagenase using $\mathrm{C}^{14}$-acetylated collagen. Anal. Biochem. 99: 340-345.

21. Laemmli, U. K. 1970. Cleavage of structural proteins during the assembly of the head of bacteriophage T4. Nature (Lond.). 222: 680-685.

22. Morrissey, J. H. 1981. Silver stain for proteins in polyacrylamide gels: a modified procedure with enhanced sensitivity. Anal. Biochem. 117:307-310.

23. Dean, D. D., and J. F. Woessner, Jr. 1984. Extracts of human articular cartilage contain an inhibitor of tissue metalloproteinases. Biochem. J. 218:277-280.

24. Welgus, H. G., J. J. Jeffrey, G. P. Stricklin, W. T. Roswit, and A. Z. Eisen. 1980. Characteristics of the action of human skin fibroblast collagenase on fibrillar collagen. J. Biol. Chem. 255:6806-6813.

25. Shimokomaki, M., V. C. Duance, and A. J. Bailey. 1981. Identification of two further collagenous fractions from articular cartilage. Biosci. Rep. 1:561-570.
26. Pelletier, J. P., J. Martel-Pelletier, D. S. Howell, L. GhandurMnaymneh, J. E. Enis, and J. F. Woessner, Jr. 1983. Collagenase and collagenolytic activity in human osteoarthritic cartilage. Arthritis Rheum. 26:63-68.

27. Woessner, J. F., Jr. 1977. A latent form of collagenase in the involuting rat uterus and its activation by a serine proteinase. Biochem. J. 161:535-542.

28. Welgus, H. G., J. J. Jeffrey, and A. Z. Eisen. 1981. The collagen substrate specificity of human skin fibroblast collagenase. J. Biol. Chem. 256:9511-9515.

29. Robinson, R. M., R. E. Taylor, and H. Birkedal-Hansen. 1984. Evidence for an extracellular plasmin-dependent proteolytic system in mineralizing matrices. Calcif. Tissue Int. 36:31-38.

30. Woessner, J. F., Jr., and M. G. Selzer. 1984. Two latent metalloproteinases of human articular cartilage that digest proteoglycan. J. Biol. Chem. 259:3633-3638.

31. Werb, Z., C. L. Mainardi, C. A. Vater, and E. D. Harris, Jr. 1977. Endogenous activation of latent collagenase by rheumatoid synovial cells. N. Engl. J. Med. 296:1017-1023.

32. Harris, E. D., Jr., and C. A. Vater. 1982. Vertebrate collagenase. Methods Enzymol. 82:423-452.

33. Amento, E. P., A. K. Bhalla, J. T. Kurnick, T. L. Clemens, M. F. Holick, and S. M. Krane. 1983. 1,25-Dihydroxyvitamin $D_{3}$ $\left(1,25(\mathrm{OH})_{2} \mathrm{D}_{3}\right)$ induces maturation of the human monocyte cell line, U937, and in association with a soluble lymphocyte factor augments mononuclear cell factor production. Calcif. Tissue. Int. 35:637.

34. Cheung, H. S., P. B. Halverson, and D. J. McCarty. 1983. Phagocytosis of hydroxyapatite or calcium pyrophosphate dihydrate crystals by rabbit articular chondrocytes stimulates release of collagenase, neutral protease and prostaglandins $\mathrm{E}_{2}$ and $\mathrm{F}_{2}$. Proc. Soc. Exp. Biol. Med. 173:181-189. 